\title{
Optimization of Rice, Mung Beans and Vegetable Planting Patterns at Paloh Border Area in Sambas Regency, West Kalimantan
}

\author{
Rusli Burhansyah ${ }^{1, *}$, Juliana Carolina Kilmanun ${ }^{1}$ and Melia Puspitasari ${ }^{1}$ \\ ${ }^{1}$ West Kalimantan Assessment Institute for Agricultural Technology
}

\begin{abstract}
The aim of this study was to analyze the pattern of planting rice, mung beans and vegetables and maximizing the income of farmers in the border area of Paloh, Sambas Regency. The study used a survey method. The unit of analysis in this study is rice farming. The sample of farmers was determined by purposive sampling on the consideration of the variety of harvested area and the types of vegetable farming that varied. The number of farmer respondents as many as 30 cases was determined by purposive sampling. To analyze the data, the income analysis and Linear Programming are used. The results showed that: farming area of 0.6 ha (arable area) can be optimized with a combination of local rice farming in the wet season of 0.6 ha. In the superior rice dry season, about 0.3 ha, mung beans 0.1 ha, mustard 0.05 ha, chilli 0.05 ha and cucumber 0.1 ha. (4) Optimal solutions can maximize farmers' income by IDR 34,818,000. To optimize rice farmyng system, green beans and vegetables with an average arable land of 0.6 ha, the recommended farming pattern is in the local rice dry season 0.6 ha, superior rice dry season 0.3 ha, mung beans 0.1 ha, mustard 0.05 ha, chili 0.05 ha and cucumber 0.1 ha.
\end{abstract}

\section{Introduction}

Scarcity of water resources occurs in this part of the world due to industrial needs, food consumption in urban areas, recreation and the agricultural sector. Factors increasing human population, higher living standards and changes in land use and global climate change also influence [11]. Future agricultural development is needed, among others; efficient utilization of scarce resources due to demand for agricultural products. Agricultural stakeholders can increase income by optimizing the use of resources to meet community demand [7]. [13] explain the strategy to increase production and sustainability in the agricultural ssector in the future is very important. Aptive landscape farming, taking into account specific soil-climatic, organizational, economic, environmental and other factors. The concept of "maximum possible grain yield" will always change upward with increasing intensification of agriculture, maintaining soil fertility, creating and introducing highly productive varieties, using a mineral nutrition system, as well as means of protection against pests and diseases, etc.

\footnotetext{
*Corresponding author: burhansyahrusli@yahoo.com
} 
Efforts to improve resource efficiency are pursued through cropping patterns. Research on cropping patterns is widely carried out by many researchers. [11] examined cropping patterns using irrigation water. The results increased from 5,904 ha to 8,051 ha $(80 \%)$ and there was a $48 \%$ irrigation efficiency. [4] say that the problem in farming in the future cropping patterns is soil acidity and soil fertility. This research was conducted in the Himalayan Piedmont region of Bangladesh. The aim of this study was to evaluate the effects of lime and fertilizer on the rice-potato-mung bean cropping pattern. The study was conducted on farmer's land for two years. There were 2 treatments, namely first dose of lime ( 1 ton/ha and 2 ton/ha) and two, administration of manure fertilizer (poultry, fertilizer and control) with three replications. Application of lime and fertilizer had an impact markedly on potato production and fertilizer residues have an effect on mung beans and rice. An increase in profits of about $45-59 \%$ from rice plants and $41-43 \%$, from mung beans. The provision of lime 1 ton/ha plus 3 ton/ ha poultry fertilizer and 5 ton / ha manure is the best treatment resulting in high production. Such treatment can increase soil $\mathrm{pH}$ and nutrient absorption by plants. [3] to optimization model for determining optimal land allocation for secondary plants in smallholding oil palm plantations in Langkat Regency to increase farmers' income levels and reduce poverty. The objective function of the model is to maximize profit for farmers. Land allocation is limited by available budgets and planting areas. In addition, the allocation is also limited by the number of plants that can be planted in each unit area because each plant requires different care procedures and has a different planting period. Each plant's yield is adjusted within a 6-month timeframe. [1] researched applied linear programming methodes the production planning system and scheduling shallots planting patterns using fuzzy time series and linear programming methods. [16] applied time series method use to predict demand on based on sales amount, while linear programming is used to assist horticulture farmers in making production planning decisions and determining the schedule of cropping patterns in accordance with demand predictions of the fuzzy time series method.

Paloh Subdistrict is a region of Sambas Regency which borders directly neighboring with Malaysia. The potential of rice food crop farming is around 8,002 ha. Besides rice, green bean plants are cultivated by farmers because of the high prices. The harvest area of mung beans is around 1,376 ha, with a production of 1,043 tons and a productivity of $0.758 \mathrm{t} /$ ha. Vegetable mustard greens, long beans, large chillies, eggplant and cucumbers [5]. The cropping patterns applied by farmers in Paloh sub-district include; in the local wet season, superior dry season, green beans, chili and cucumber.

The problem at the farm level is that there is no planning for planting patterns that maximizes profits. For this reason research in cropping patterns is needed that maximizes farmers' income. The purpose of this study was to determine the planting patterns of rice, green beans and vegetables in the border region of Sambas Regency.

\section{Research Method}

\subsection{Location and Time of Research}

This research uses survey method. The method is a systematic method for gathering information from a population sample with the aim of describing a quantitative description of a larger population [15]. The study was conducted in 3 villages in Paloh sub-district with the consideration that three villages already had broader rice and vegetable planting patterns than the other villages. These villages include: Tanah Hitan Village, Matang Danau Village and Kalimantan. Research time was in October to December 2018. 


\subsection{Data Processing and Sampling Methods}

The study was directed at farmers who planted rice, green beans and vegetables based on information from Field Agricultural Extension Paloh District. Furthermore, to get farmers who became respondents conducted random sampling. The number of respondents were 30 people.

\subsection{Data Processing and Analysis Techniques}

The collected data is then presented in tabular form. To calculate the income of farmers from farming rice, green beans and vegetables, the writers use the analysis of gross income, analysis of net income with the following formulation [12].

$$
G M=G F I-T V C
$$

$$
N F I=C F I-T V C-T F C
$$

Where:

$$
\begin{array}{ll}
\text { GM } & =\text { Gross margin } / \text { ha } \\
\text { GFI } & =\text { Gross farm income } / \text { ha } \\
\text { TVC } & =\text { Total variable cost } / \text { ha } \\
\text { TFC } & =\text { Total fixed cost } / \mathrm{ha} \\
\text { NFI } & =\text { Net farm income } / \mathrm{ha}
\end{array}
$$

The QM for window v5 Programming linear program was used to solve the problem of optimizing rice, mung beans and vegetables farming [8] with the following models:

\section{Purpose Function:}

Functions that maximize income from various activities (types of rice, mung beans, and vegetables farming) mathematically as follows [9].

Maximize

Where:

$$
Z=C_{1} X_{1}+C_{2} X_{2}+\cdots C_{j} X_{J}
$$

$\mathrm{Cj} \quad=$ parameters used as optimization criteria or the $\mathrm{j}$ th decision-making coefficient change in the objective function (objective function coefficient), namely the net income of each farming activity.

$\mathrm{Xj} \quad=$ Changes in decision making or activities (to be sought), namely types of rice farming, green beans, vegetables

$\mathrm{Z}=$ value of decision-making criteria; an objective function; or optimized value

Constraint function:

The constraint function is the availability of agricultural resources owned by farmers. Mathematically formulated as follows:
$\mathrm{a}_{11} \mathrm{X}_{1}+\mathrm{a}_{12} \mathrm{X}_{2}+\mathrm{a}_{13} \mathrm{X}_{3}+\ldots \ldots \ldots \ldots+\mathrm{a} 1_{\mathrm{j}} \mathrm{X}_{\mathrm{j}} \leq \mathrm{b}_{1}$
$a_{21} X_{1}+a_{22} X_{2}+a_{23} X_{3}+\ldots \ldots \ldots \ldots+a 2_{j} X_{j} \leq b_{2}$
$a_{31} X_{1}+a_{32} X_{2}+a 3_{3} X_{3}+\ldots \ldots \ldots \ldots+a 3_{j} X_{j} \leq b_{3}$
${ }_{\text {ai } 1} X_{1}+a_{12} X_{2}+a_{3} X_{3}+\ldots \ldots \ldots \ldots \ldots+a_{i j} X_{j} \leq b_{i}$
and non-negative conditions
$\mathrm{Xj} \geq 0$, for $\mathrm{j}=1,2, \ldots \ldots, \mathrm{n}$ 
Where:

aij $=$ the coefficient of technological change in decision-making $\mathrm{j}$ in the first obstacle, namely the use of agricultural resources per ha

bi $=$ limited $\mathrm{i}$ resource which discusses activities

$\mathrm{Xi}=$ changes in decision making or activities (to be sought), namely types of rice farming, mung beans, vegetables.

$\mathrm{I}=$ the number of agricultural resources that is a constraint

$\mathrm{J}=$ Change number of decisions - making (activity)

Next, the linear programming planning model was solved using the simplex method with the linear programming matrix model. In addition to the optimal solution, sensitivity or post optimal analysis was also performed

\section{Result and Discussion}

\subsection{Geographical Location, Climate and Planting Pattern}

Geographically Paloh sub-district is located between 1035 '35 " until 2005 '43' 'North Latitude and 109038 '56 "to 109028 '27" East Longitude. Paloh Subdistrict is located in the north of Sambas Regency which borders directly with Sarawak Country in eastern Malaysia. This sub-district is a coastal area which has the longest coastline in Sambas district. Paloh Subdistrict has an area of 1,148.84 km2 (114,884 ha) or 17.96 percent of the area of Sambas district [5].

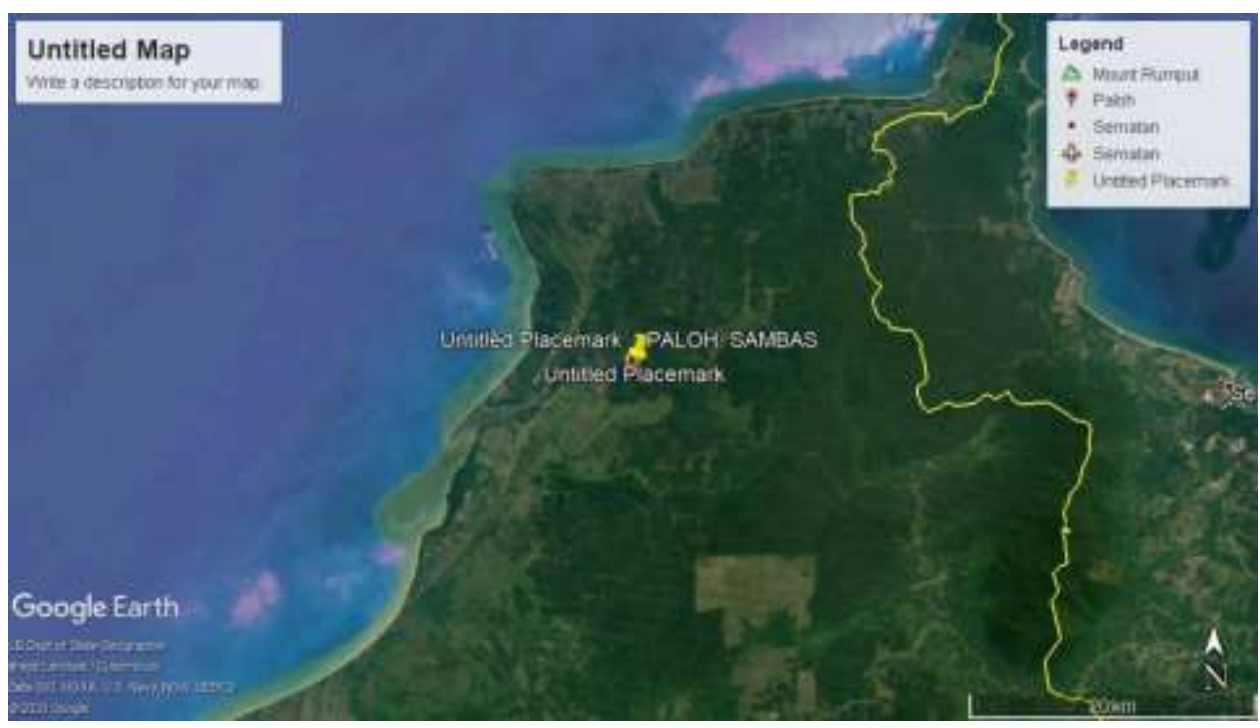

Fig. 1. Paloh sub-district map

Based on data on average rainfall in 2011-2017 in the District of Paloh, the average per month is around $223 \mathrm{~mm}$. The rainy season starts from September / October to February. The dry season starts from March / April to August (Figure 2). 


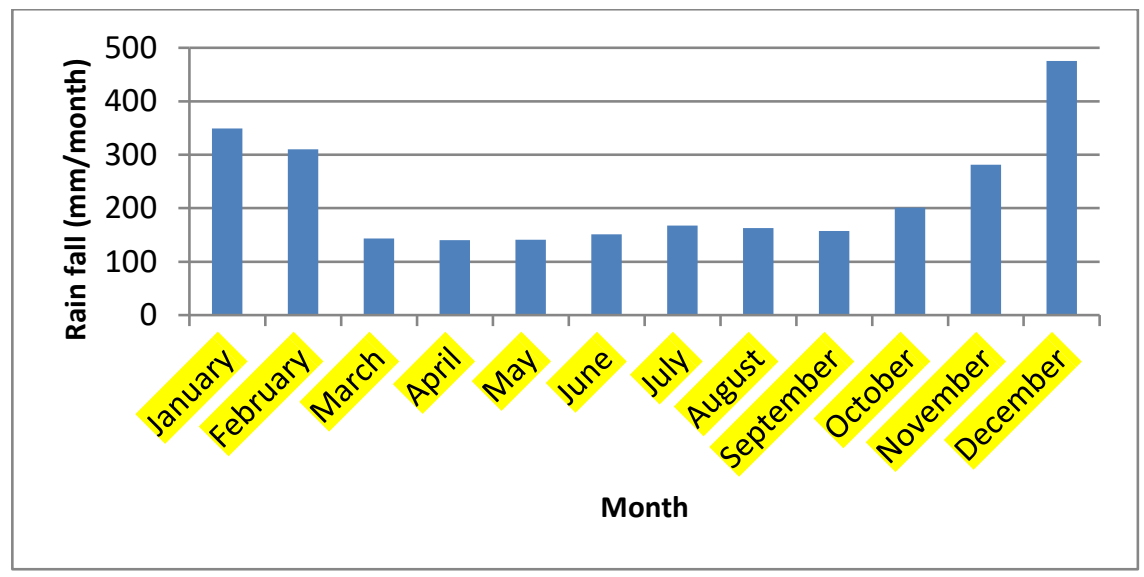

Fig.2. Average rainfall in 2011-2017 in Paloh District

Based on the results of the FGD at the farmer level, the cropping patterns in the rainy and dry seasons are obtained as follows (Figure 3)

\begin{tabular}{|c|c|c|c|c|c|c|c|c|c|c|c|c|}
\hline & Jan & Peb & Mar & Apri & May & June & July & Aug & Sept & Octo & Nov & Dec \\
\hline \multicolumn{13}{|l|}{ Local Rice } \\
\hline \multirow{2}{*}{\multicolumn{13}{|c|}{$\begin{array}{l}\text { Mung bean } \\
\text { Superior } \\
\text { Rice }\end{array}$}} \\
\hline & & & & & & & & & & & & \\
\hline \multicolumn{13}{|l|}{ Collards } \\
\hline Chili & & & & & & & & & & & & \\
\hline Cucumber & & & & & & & & & & & & \\
\hline
\end{tabular}

Fig.3. Planting Patterns in Paloh District

The dominant types of food and vegetable commodities cultivated by farmers in the Paloh border region are local rice, New Superior Variety rice (Inpari 43), mung beans, collards, chili and cucumber. Generally the cropping patterns applied by farmers are monoculture. In the wet season the land is planted with local rice, dry season rice is planted with superior rice, mung beans, collards, chili and cucumber.

\subsection{The Costs and Benefits of Farming}

The results of the analysis of farmer income per hectare based on the type of farming carried out by farmers are presented in Table 1 below. From the results of the income analysis (Table 1), it is known that the biggest income from six farming activities with an average of 0.6 ha is chilli farming, which is IDR 29,288,000 / grp. Of all the farming activities, collards farming provides the smallest income, which is IDR 885,000 . The highest $\mathrm{B} / \mathrm{C}$ ratio was 3.51 for chili farming, the lowest $\mathrm{B} / \mathrm{C}$ ratio was 1.94 for local rice farming.

Farm size, production cost and revenue and cost ratio (B/ $\mathrm{C}$ ratio) are important aspects in farm planning. Issues of farming area and production costs will be important in determining the types of plants that will be cultivated if farmers are faced with limited resources, both land area, capital for production facilities and paying labor costs. The implication, although a farm can provide the highest income, is not necessarily the best option 
to implement because the size and type of farming are related to production costs. How to determine the type of farming activity by considering the limitations of agricultural resources owned so that optimal farming (can maximize income). The results of the analysis applying linear programming presented below can solve this problem.

Table 1. Costs and Income per Cultivation of Various Food Crops and Vegetable Farming in Paloh, 2018

\begin{tabular}{|c|c|c|c|c|c|c|c|}
\hline \multirow[b]{2}{*}{ No } & \multirow[b]{2}{*}{ Description } & \multicolumn{6}{|c|}{ Type of Farming *) } \\
\hline & & Local Rice & VUB Rice & $\begin{array}{l}\text { Mung } \\
\text { Bean }\end{array}$ & Collards & Chili & Cucumber \\
\hline \multirow[t]{4}{*}{1} & $\begin{array}{l}\text { Production } \\
\text { Facilities }\end{array}$ & & & & & & \\
\hline & $\begin{array}{l}\text { Seeds / Seeds cost } \\
\text { (IDR) }\end{array}$ & 200,000 & 300,000 & 450,000 & 570,000 & 512,000 & $2,100,000$ \\
\hline & Fertilizer cost (IDR) & 450,000 & $1,300,000$ & 525,000 & 200,000 & $2,650,000$ & $2,300,000$ \\
\hline & $\begin{array}{l}\text { Pesticides cost } \\
\text { (IDR) }\end{array}$ & 350,000 & 750,000 & 200,000 & 250,000 & $1,500,000$ & 300,000 \\
\hline 2 & Labor cost (IDR) & $3,710,000$ & $5,475,000$ & $1,950,000$ & $4,250,000$ & $5,000,000$ & $3,750,000$ \\
\hline 3 & Fixed cost (IDR) & $1,200,000$ & $1,200,000$ & 700,000 & $1,000,000$ & $2,000,000$ & 800,000 \\
\hline 4 & Total Costs & $5,910,000$ & $9,025,000$ & $3,825,000$ & $6,270,000$ & $11,662,000$ & $9,250,000$ \\
\hline 5 & Production (IDR) & 2,200 & 3,700 & 650 & 1,000 & 2,730 & 3,845 \\
\hline 6 & Revenue (IDR) & $11,440,000$ & $18,500,000$ & $9,100,000$ & $7,155,000$ & $40,950,000$ & $26,915,000$ \\
\hline 7 & Benefit (IDR) & $5,530,000$ & $9,475,000$ & $5,275,000$ & 885,000 & $29,288,000$ & $17,665,000$ \\
\hline 8 & $\mathrm{~B} / \mathrm{C}$ ratio & 1.94 & 2.05 & 2.38 & 1.14 & 3.51 & 2.91 \\
\hline
\end{tabular}

*) Average arable area of 0.6 ha

\subsection{Farm Optimization}

The results of the optimization analysis include solving primal and dual problems and sensitivity analysis. This analysis considers 6 farming activities with 14 types of agricultural resources with an average area of arable land based on respondents is 0.6 ha.

\subsubsection{Primal Settlement}

The results of the analysis with linear programming obtained optimal solutions or maximizing farmers' income in the average area of 0.6 ha. The area and type of plant (combination) arrangement of farms cultivated in this area can be shown from the results of primal settlement (Table 2).

There are 2 activities that enter the base with a value of $\mathrm{Z} \max =34,818,000$. This means that the combination of the two farms on an area of arable land of an average of 0.6 ha can maximize farmers' income in the Paloh border region, which is as much as IDR 34,818,000.

It can be assumed that the selected farming activities in the optimal solution include local rice farming and chilli farming included in the base. From an average of 0.6 ha of arable land will provide maximum total income with an allocation of that value. The arrangements are: for local rice farming of 0.6 ha and chilli farming 0.05 ha. Both activities are carried out with a monoculture pattern in different seasons. The combination of farming activities with the arrangement of farming area will maximize the farmer's total income, in the amount of IDR $34,818,000$. 
Table 2. Results of Linear Programming Analysis on Primal settlement

\begin{tabular}{|l|l|c|c|r|}
\hline Variable & $\begin{array}{c}\text { Farming } \\
\text { Activities }\end{array}$ & Status & Value (ha) & $\begin{array}{c}\text { Reduced Cost } \\
\text { (IDR) }\end{array}$ \\
\hline X1 & Local rice & Basis & 0,6 & 0 \\
\hline X2 & Superior rice & Non Basis & 0 & 19.813 .000 \\
\hline X3 & Mung bean & Non Basis & 0 & 24.013 .000 \\
\hline X4 & Collards & Non Basis & 0 & 28.403 .000 \\
\hline X5 & Chili & Basis & 0,05 & 0 \\
\hline X6 & Cucumber & Non Basis & 0 & 11.623 .000 \\
\hline $\begin{array}{l}\text { Final Optimal Solution } \\
\text { Z max }=34.818 .000\end{array}$ & & & \\
\cline { 2 - 5 }
\end{tabular}

The reduced cost value for activities that are included in the basis is 0 , meaning that the scale of entrepreneurship for those activities has provided maximum income and is not profitable if the scale of exploitation is done. Based on the results of primal settlement analysis, the magnitude of the scale of the activity suggested is indicated by the magnitude of the values as previously described. Farming activities that are not included on a non-basis basis have a reduced cost value. This shows that if the resources are allocated for these activities, each allocation unit will actually reduce the total income in the optimal solution by the value of reduced cost. Therefore, the two farming activities, namely local rice and chili are not included in the optimal solution (value equal to zero).

The results of the study by [14] showed that the optimal planting pattern would produce a maximum income of IDR 76,568,940.00 per period of rice planting season is rice and mustard greens for the first planting season and lettuce for the second planting season. Based on primal analysis, with limited capital available, the area of land that can be planted each season is $0.30 \mathrm{Ha}$ for rice plants in the first planting season, $0.26 \mathrm{Ha}$ for mustard plants in the first planting season, and $0.26 \mathrm{Ha}$ for the second planting season.

\subsubsection{Dual Settlement}

In addition to the primal settlement which points to the optimal solution of the objective function, important information obtained from the results of the optimization analysis is an evaluation of the use of agricultural resources shown in the dual settlement (Table 3 ). In Table 3 below there are 13 agricultural resources available, there are 2 agricultural resources with binding status, while other non-binding resources. Agricultural resources that have binding status indicate that these resources are limited and used up in an optimal solution ( slack value $=$ zero) or there are no leftovers (Table 3 ).

This depleted agricultural resource covers the area of the wet season and the area of the dry season by having a dual value (dual value / shadow price) as in Table 3 . In theory the production is referred to as the marginal product value. A dual value states that each additional use of resources by one activity unit will add to the optimal value of the dual value. A dual value of the width of the wet season claim of 55.30 means that each addition of arable area (other resources remains) will increase the optimal revenue solution of IDR 5,530,000. While the dual value of the width of the dry season arable is 29.28 meaning that each additional arable area (other resources remains) will increase the optimal income solution of IDR 29,288,000. Other resources that have non-binding status means that the resource still has slack or is overused or not used because it is not included in the optimal solution, so the dual value is zero. This means that increasing the use of these resources does not increase revenue for optimal solutions. 
Table 3. Results of Linear Programming Analysis in Dual Resolution

\begin{tabular}{|l|l|l|l|l|l|}
\hline \multirow{2}{*}{ Resources } & Constraints & Status & $\begin{array}{l}\text { Slack/ } \\
\text { Surplus }\end{array}$ & $\begin{array}{l}\text { Dual Value/ } \\
\text { Shadow } \\
\text { Price }\end{array}$ \\
\cline { 2 - 4 } & Unit & Symbol & & & \\
\hline Arable area Rain Season & ha & C1 & Binding & 0 & $5,530,000$ \\
\hline Arable area Dry season & ha & C2 & Binding & 0 & $29,288,000$ \\
\hline Local Rice Seed & $\mathrm{kg}$ & $\mathrm{C} 3$ & Non Binding & 199,960 & 0 \\
\hline Superior rice seed & $\mathrm{kg}$ & $\mathrm{C} 4$ & Non Binding & 300,000 & 0 \\
\hline Mung bean seed & $\mathrm{kg}$ & $\mathrm{C} 5$ & Non Binding & 450,000 & 0 \\
\hline Collard seed & $\mathrm{gr}$ & $\mathrm{C} 6$ & Non Binding & 570,000 & 0 \\
\hline Chili seed & $\mathrm{gr}$ & $\mathrm{C} 7$ & Non Binding & 511,984 & 0 \\
\hline Cucumber seed & $\mathrm{gr}$ & $\mathrm{C} 8$ & Non Binding & $2,100,000$ & 0 \\
\hline Urea fertilizer & $\mathrm{kg}$ & $\mathrm{C} 9$ & Non Binding & $1,349,800$ & 0 \\
\hline NPK fertilizer & $\mathrm{kg}$ & $\mathrm{C} 10$ & Non Binding & $3,374,400$ & 0 \\
\hline KCl fertilizer & $\mathrm{kg}$ & $\mathrm{C} 11$ & Non Binding & $2,699,900$ & 0 \\
\hline Labor in the family & $\mathrm{HOK}$ & $\mathrm{C} 12$ & Non Binding & $24,134,930$ & 0 \\
\hline Labor outside the family & $\mathrm{HOK}$ & $\mathrm{C} 13$ & Non Binding & $24,134,900$ & 0 \\
\hline
\end{tabular}

\subsection{Sensitivity Analysis}

Sensitivity analysis is used to identify critical variables that are uncertain and adopted in the uncertainty analysis of the Monte Carlo Simulation that was developed. The method for sensitivity analysis cannot be expected to be exactly the same for all models [6]. Sensitivity analysis in the Linear Program is used to estimate the amount that is difficult to estimate after optimal [10]. Furthermore, [2] stated that there are three approaches in sensitivity analysis namely first using a base, second approach using an optimal partition and third using an optimal value. The purpose of the sensitivity analysis is to reduce the calculation and avoid re-calculation, if there are changes in one or several coefficients when the optimal completion has been achieved.

On completing objective row ranges (Table 4), it can be seen that from activities that are included in the basis of being sensitive to changes in income, chili farming (X5) has an optimal minimum program limit is more sensitive to income decline than other activities because it has a sensitivity range of at least $40 \%$, then X1 (local rice farming) is less sensitive to decreasing income because it has a wider allowable decrease of $100 \%$.

Table 4. Value of the range of sensitivity of the objective function coefficients in the objective row ranges objective Coefficient Ranges

\begin{tabular}{|l|l|l|l|l|l|l|}
\hline $\begin{array}{c}\text { Farming } \\
\text { Activities }\end{array}$ & $\begin{array}{l}\text { Varia } \\
\text { ble }\end{array}$ & $\begin{array}{c}\text { Lower } \\
\text { Limit }\end{array}$ & $\begin{array}{c}\text { Current } \\
\text { Value }\end{array}$ & $\begin{array}{c}\text { Upper } \\
\text { Limit }\end{array}$ & $\begin{array}{c}\text { Allowable } \\
\text { Increase }\end{array}$ & $\begin{array}{l}\text { Allowwabl } \\
\text { e Decrease }\end{array}$ \\
\hline Local rice & X1 & 0 & 5.530 .000 & No Limit & No Limit & 0 \\
\hline Inpari 43 & X2 & No Limit & 9.475 .000 & 29.288 .000 & 38.763 .000 & No Limit \\
\hline Mung bean & X3 & No Limit & 5.275 .000 & 29.288 .000 & 34.563 .000 & No Limit \\
\hline Collards & X4 & No Limit & 885.000 & 29.288 .000 & 30.173 .000 & No Limit \\
\hline Chili & X5 & 17.655 .000 & 29.288 .000 & No Limit & No Limit & 11.633 .000 \\
\hline Cucumber & X6 & No Limit & 17.665 .000 & 29.288 .000 & No Limit & No Limit \\
\hline
\end{tabular}

The next sensitivity analysis is the situation where if there is a change in the supply of land resources used. The range of sensitivity of agricultural resources included in the status bindings appears in the completion of the right-hand side ranges (Table 5), which explains 
the sensitivity of the optimal program value to changes in the availability of resources or the right value. From the results of sensitivity analysis in completing the right hands side ranges, there are 2 which have binding status, namely the width of the rainy season and the width of the dry season. Both of these resources are used up in optimal solutions. The area covered by the Rainy Season is around 5,000 ha and the dry season is 6,749 ha.

Table 5. Value of the Range of Agricultural Resource Sensitivity in Right Hand Side Ranges

\begin{tabular}{|c|c|c|c|c|c|c|c|}
\hline \multicolumn{3}{|c|}{ Constraints } & \multirow{2}{*}{$\begin{array}{l}\text { Lower } \\
\text { Limit }\end{array}$} & \multirow{2}{*}{$\begin{array}{c}\text { Curre } \\
\text { nt } \\
\text { Value } \\
\text { s }\end{array}$} & \multirow{2}{*}{$\begin{array}{l}\text { Upper } \\
\text { Limit }\end{array}$} & \multirow{2}{*}{$\begin{array}{c}\text { Allowab } \\
\text { le } \\
\text { Increase }\end{array}$} & \multirow{2}{*}{$\begin{array}{l}\text { Allowable } \\
\text { Decrease }\end{array}$} \\
\hline Resources & Unit & $\begin{array}{c}\text { Symb } \\
\text { ol }\end{array}$ & & & & & \\
\hline $\begin{array}{l}\text { Arable area } \\
\text { Rain Season }\end{array}$ & ha & $\mathrm{C} 1$ & 0,6 & 0,6 & 5.000 & 1,2 & 0 \\
\hline $\begin{array}{l}\text { Arable area } \\
\text { Dry Season }\end{array}$ & ha & $\mathrm{C} 2$ & 0,6 & 0,6 & 6.749 & 1,2 & 0 \\
\hline
\end{tabular}

The implication is that if farmers can increase their use of both land resources, it can provide higher income for optimal solutions. This is supported by the results of the analysis on the dual solution as previously described (Table 3) where both resources have a shadow price or dual value which means that each additional use of resources by one activity unit will add to the value of the solution for its dual value.

\section{Conclusion and Suggetsion}

The results showed that: (1) the average area of arable land by farmers in the Paloh Border area was 0.6 ha and there were 6 types of commodities dominantly cultivated by farmers including local rice, superior rice, mung beans, collards, chili, and cucumber; (2) farmer's income from local rice farming Farmer's income from local rice farming is IDR 5,530,000, superior rice IDR 4,475,000, mung beans IDR 5,275,000, collards IDR 885,000, chili IDR $29,288,000$ and cucumber IDR 17,665,000, (3) farming of 0.6 ha (arable area) can be optimized with a combination of local rice farming in the wet season of 0.6 ha. In the dry season, superior rice is around 0.3 ha, mung beans are 0.1 ha, collards 0.05 ha, chili 0.05 ha and cucumber 0.1 ha. (4) optimal solution can maximize farmers' income of IDR 34,818,000

The recommended farming patterns so that the total income of farmers in the Paloh Border area for a maximum area of 0.6 ha arable is superior rice about 0.3 ha, mung beans 0.1 ha, collards 0.05 ha, chili 0.05 ha and cucumbers 0.1 ha. The sensitivity analysis shows that the used resources are the Rainy Season and the Dry Season. The optimal solution for the rainy season is around 5,000 ha and the dry season is 6,749 ha.

\section{Refrences}

1. A D.Indriyanti, D. R. Prehanto, G.S. Permadi, C.Mashuri, T.Z. Vitadiar. E3S Web of Conferences 125, 23007 ICENIS 2019 (2019)

2. B. Jansen 2, JJ. De Jong, C. Roos, T. Terlaky. European Journal of Operationsl Research.(1997)

3. B.D.B.S. Sitorus, R.D.Kusumastuti. $1^{\text {st }}$ Asia Pacific Business and Economics Conference (APBEC 2018). (2019).

4. B.S. Sultana, M.H Main, M Jahiruddin, M.Z Rahman, M.N.E.A Siddique and J Sultana.. L. Asian Journal Agricultural and Horticultural Research. 3,2(2019)

5. BPS Kabupaten Sambas, Kabupaten Sambas dalam angka 2018. BPS (2018) 
6. Eriksson,. Thesis, Linkoping University Faculty of art and Sciences. (2007)

7. H. Mohmmad H and F Bostani. Journal Of Agricultural Economics Researches, 1,3(2009)

8. H.A. Taha. Operation Research. An Introduction.(University of Arkansas, Fayetteville. (C) Pearson Education Limited,(2017)

9. I.D. Anna, S.B.Febrian. 2nd International Conference on Social Science (ICSS 2019) (2019)

10. J.L.Higle, S.W.Wallance. Interface 33,4 (2003)

11. K.T. Birhani, T Alamirew, MD Olumana, S Ayalew and D Aklog.. Irrigat Drainage Sys Eng 4,2 (2015)

12. N.Mamun, Departemen of Agricultural Economic University of Nigeria, Nsukka. (2013)

13. O.Makarova, V.Makarov, S.Gasparyan, Z.Napris, A.Shemyakin. E3S Web of Conferences 175, 01003 (2020)

14. R.Khalik, Safrida, A.H.Hamid. J.Agrisep 14,1(2013)

15. R.M, Groves, F.J.Jr. Fowler, M.P.Couper, J.M.Lepkowski, E.Singer, R.Tourangeau. Survey Methodology.(John Wiley and Sons, Inc, 2009).

16. T.Z. Vitadiari,, F.Farikhin, B.Surarso . E3S Web of Conferences 31, 10004 (2018) 